\title{
漢方製剤の「証」分類からみた 気・血・水と良導絡の関連について
}

東京都調布市 杉田医院・漢方良導絡研究所 杉 田 好 朝

\section{〔緒 兽〕}

私は、組成生薬の「証」分類を基に医療用薬 方エキス製剤（135 方剂）の帰経・八綱・気血 水・燥湿・升降について、「証」分類を行ない、 この漢方製剤の「証」分類の結果を疾患・病 証・症候別治療代表方剂に適用して検討した結 果、漢方製剤がそれぞれの「証」に相対して選 択されている事実と、良導絡診断と漢方の「証」 の関連を認め、前日本良導絡自律神経学術大会 と日良自律学会誌で発表しました。

\section{〔方 法〕}

その際、漢方製剤の「証」分類の方法及び治 療方剤の「証」分類との比較検討方法について 述べましたので省略しますが、病証別の項で、 中医学診断治療加らた気・血・津液の病証別 治療代表方剤の「証」分類の検討により、気・ 血・津液の病証においてあ気・血・水証に対応 した方剂で治療されている事実並びに治療方剂 の「証」と帰経との関連について述べました。 今回は、医療用漢方製剤の「証」分類からみ た、気・血・水証用方剂と帰経との関連を検討 し、両結果を併わせて気・血・水と良導絡の関 連を検討しましたので報告します。

\section{〔結 果〕}

先ず、既に発表しました病証別治療代表方剤 の「証」分類から気・血・津液の病証別代表方剂 が対応する㷌経と気血水証についてみますと、

(1) 気の病証の代表方剂では、肺・心包・ 心・脾・胃経にヤ、三焦経に个と、気証 にヤがみられ、

(2) 津液の病証の代表方剤では、肺・脾・胃 経にへと、気証・水証にへがみられま す。
(3) 血の病証の代表方剤では、心・肝・腎・

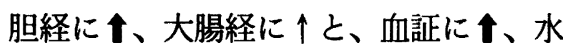
証に个がみられ、

(4) 気血同病証の代表方剤では、肺・心・ 脾・肝・腎経に、、胆経に个と、血証に

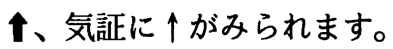

このように、気・血・津液の各病証によっ て、相対する帰経と気・血・水証に上昇がみら れました。

以上は、治療方剂の「証」分類からみた検討 の結果でありますが、今回は、135 漢方製剤の 「証」分類からみた検討を加えました。

組成生薬の数と量からみた漢方製剤の気・ 血・水「証」分類を行った結果は、既に報告し ましたが、気証・血証・水証・気血証・気水 証・血水証・気血水証の各証に対応する方剤之 して分類できます。

この気血水各証に対応する漢方方剂別に列記 して、各漢方製剤の「証」分類を適用した結果 と全製剤の「証」分類結果を比較して、従来之 同じ方法で検討しました。

その結果、気血水証用方剤と帰経についてみ ますと、

(1) 気証に対応する方剤では、肺・胃経に ヤ、脾・肝経に个がみられ、

(2) 血証に対応する方剂では、心・肝経に がみられ、

(3) 水証に対応する方剤では、心・脾経に ヤ、大腸・腎経に个がみられます。

(4) 気・血証に対応する方剤では、心包・肝 経にヤ、肺・心・胆経に个がみられ、

(5) 気・水証に対応する方剂では、漢方製剤 の半数以上（50.37\%） を占めるため、 気・水証の湿証用方剂と、湿燥中間証用 方剂と燥証用方剂に分類列挙して、三者 
を一括した結果、気・水証用方剂では、

肺・脾・胃経にヤがみられます。

(6) 血・水証に対応する方㓮では、心・小

腸・大腸・肝・腎・胆経にヤがみられ、

(7) 気・血・水証全てに対応する方郕では、 小包・心・小腸・三焦・肝・腎・胆経に

ヤ、脾経に个がみられます。

以上を、気証・血証・水証に関連する方剤と して緾めますと、

(1) 気証に関連する方剤では、肺・胃経に

ヤ、脾経に个がみられ、
(2) 血証に関連する方剤では、心包・心・大 腸・肝・胆経に十、小腸・腎経に个がみ られ、

(3) 水証に関連する方剤では、製剤の $77 \%$ が水証に関連しているので、全製剂と比 較してヤはみられず、腎経に个がみられ ます。

以上述べました、気・血・津液病証別治療代 表方剤之、気・血・水証用方剤の帰経について 一括表示しますと、この表の上部のようになり ます。

\section{気・血・津液病証別代表治療方剂と} 気・血・水証用方剂の帰経・八絲

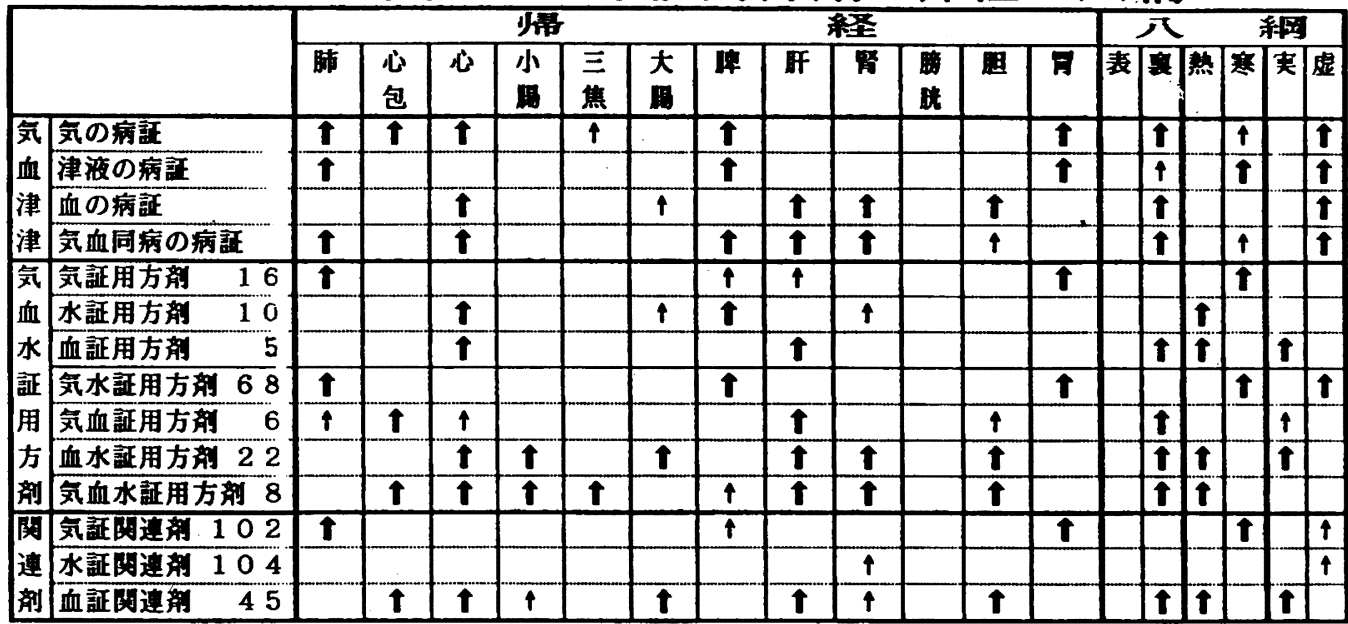

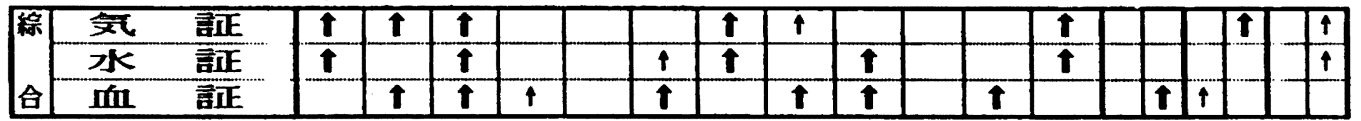

この上部の表を綜合して、気証・血証・水証 之㸟経の関連を、気証・水証・血証の順に下部 に緾めてみますと、

(1) 気証は、肺・心包・心・脾・胃経に $\boldsymbol{\uparrow}$ と、肝経に个の関連がみられます。

(2) 水証は、肺・心・脾・胃経にヤに加え て、腎経にヤ大大腸経にヤの関連がみら れます。

(3) 血証は、心包・心・腎経にヤに加えて、 大腸・肝・胆経にヤと、小腸経に个の関 連がみられます。

その結果、気血水之四要と帰経は異なる観点 からみた分類でありますが、漢方治療方剤の
「証」分類からみた気証・水証・血証之帰経と の関連之、病位の再分類からみた四要の衛 ・ 気・営・血と帰経との関連が類似していること を認めました。

\section{〔結 論〕}

結論として、

気・血・津液病証別漢方治療方剂の「証」分 類之、漢方製剂 135 方剂の気・血・水証用方剂 別の「証」分類を行ない、両結果を併せて気・ 血・水之帰経との関連を比較検討し、気・血・ 水と良導絡の関連を認めました。 